\title{
Can VPIN Forecast Geopolitical Events? Evidence from the 2014 Crimean Crisis*
}

\author{
Felipe Bastos G Silva ${ }^{1}$ and Ekaterina Volkova ${ }^{2}$ \\ ${ }^{1}$ Cornell University \\ Samuel C. Johnson Graduate School of Management \\ 301M Sage Hall, Ithaca, NY, 14850, USA \\ fbs27@cornell.edu \\ ${ }^{2}$ University of Melbourne \\ Faculty of Business and Economics \\ 198 Berkeley St, Carlton VIC 3052, Australia \\ ekaterina.volkova@unimelb.edu.au
}

December 22, 2017

\begin{abstract}
We study the recent Crimean Crisis and the sequence of outcomes that led to the intervention by the Russian Army, which directly affected equity prices in Russia, to investigate how informed traders may have used their advantage to trade prior to the moment markets fell. We compute the Volume-synchronized Probability of Informed Trading (VPIN) for the Russian RTS equity index and for individual stocks, documenting that levels of informed trading increased considerably between one and three trading days before market prices reflected the invasion. We also investigate the predictive power of the cumulative distribution of VPIN on future stock prices, showing a statistically significant (negative) relation during the period of elevated tensions between Russia and Ukraine. Last, we investigate the levels of VPIN measured for global depositary receipts (GDRs) of Russian firms, documenting a similar increasing pattern prior to the invasion date but generally subsequent to the spikes obtained from the corresponding securities locally traded in Russia. Overall, our results provide additional support for the use of VPIN as a tool for monitoring the likelihood of undesirable geopolitical events.
\end{abstract}

*We thank Warren Bailey, Andrew Karolyi, Kenneth Merkley, Roni Michaely, Maureen O'Hara, Gideon Saar, Blake Steenhoven, and Patrick Witz for their insightful comments and suggestions. We also thank Leonid Bershidsky (Bloomberg), Carl Schreck (Radio Free Europe), Geraldo Samor (VEJA Mercados, Brazil Journal), Matt O'Brien (Washington Post), Paula Barra (InfoMoney), and Andreas Sator (DerStandard) for their interest in this paper. 


\section{Introduction}

Can trade imbalances be used to forecast market crashes following geopolitical crises? The purpose of the present work is to investigate the effects on the levels of inside trading activity for different equities in an emerging economy given a quasi-exogenous event.

We focus our study on the invasion of the Crimean region of Ukraine by the Russian Army in February of 2014, which followed months of escalating tensions between Russia and Ukraine, which started after the Ukrainian president Viktor Yanukovych signaled a shift from a trade agreement with the European Union towards an economic approximation to the Russian Federation. We investigate the relationship between stock returns and the volume-synchronized probability of informed trading (VPIN, as in Easley, López de Prado, and O'Hara 2011, 2012) as the crisis between the two nations evolved and information was incorporated into stock prices. ${ }^{1}$

We consider the methodology proposed by Easley, López de Prado, and O'Hara (2012) and compute the corresponding VPIN levels of the Russian RTS equity index and individual Russian equities, documenting an unusual spike in VPIN levels and its cumulative distribution a few days prior to the military intervention and the subsequent drop on stock prices. We then expand our event study to a two month time frame of increasing tensions between both countries and investigate the predictive power of the cumulative distribution of VPIN on future stock returns in a panel analysis, showing that higher values of the cumulative distribution of VPIN are associated with subsequent negative returns. We fail to find evidence that this relationship is affected by short-selling constraints or direct government equity ownership. We further extend our analysis to Russian firms that, in addition to securities traded in local markets, also have depositary receipts traded in London or other European stock exchanges, showing that while similar patterns of VPIN spikes are observed, the timing in which maximum values are reached is normally earlier for the local securities.

The probability of informed trading measure (PIN) originally developed by Easley, Kiefer, O'Hara, and Paperman (1996) is largely employed in the literature as a proxy for the degree of information asymmetry of a given firm and is shown to have a direct effect on the firm's cost of capital as a priced factor that explains the cross-section of stock returns (see Duarte and Young 2009, Easley and O'Hara 2004, Easley, Hvidkjaer, and O'Hara 2002). In spite of its academic success, the recent phenomenon of high frequency trading (HFT) firms comprising an increasingly relevant fraction of the trading volume made the estimation of PIN values based on the estimation of unobserved parameters - literally impracticable. ${ }^{2}$ To accommodate this empirical fact, the volume-time variant of PIN (or simply VPIN) was developed by Easley, López de Prado, and O'Hara (2012) and is shown to have predicted the flash crash that occurred in the U.S. equity market in May 6, 2010 (Easley, López de Prado, and O'Hara 2011). ${ }^{3}$ In a high frequency world, trade time rather than chronological (clock) time is the relevant metric to proxy for the evolution of the information set (Ané and Geman 2000).

Our paper is related to a body of literature that studies the effects of wars and political crises on financial markets. Frey and Kucher (2000) study the behavior of bond prices in five European nations (Germany, France, Belgium, Austria and Switzerland), given a sequence of

\footnotetext{
${ }^{1}$ As most geopolitical crisis, escalation evolves gradually and the military invasion itself cannot be labeled as an abrupt exogenous shock. However as tensions evolve and the odds associated with the direct and indirect outcomes of a military intervention - economic externalities and possible sanctions from Western nations become more likely to take place, information gets incorporated to market prices.

${ }^{2}$ The estimation is typically performed by counting the number of buy-initiated and sell-initiated trades for a given trading day following the Lee and Ready (1991) algorithm and optimizing a log-likelihood function derived from the information model proposed by Easley, Kiefer, O'Hara, and Paperman (1996).

${ }^{3}$ In fact since 2009 high frequency traders account for more than $70 \%$ of the trading volume in U.S. equity markets even though such firms comprise roughly $2 \%$ of the trading firms in the country.
} 
specific events that affected them in pre-, during, and post-WWII periods. Amihud and Wohl (2004) analyzes the link between expectations of the fall of Saddam Hussein and stock prices by using prices of a prediction markets website. Leigh, Wolfers, and Zitzewitz (2003) extend the analysis of the price of prediction markets to macroeconomic variables, delving into U.S. data (industry-wise effects of equity prices) and international stock markets (Turkey, Israel, and several European nations), concluding that countries which are highly globalized and net importers of oil were consequently more affected by the negative effects of the war.

Because of the relative fragility of democratic institutions and political and economic instability, stock markets from emerging economies are normally more sensitive to local and global political risks relative to markets from their developed peers (see Karolyi 2015, for a detailed review on emerging markets). For instance, Bailey and Chung (1995) show that equity market premiums of Mexican individual securities are exposed to political and exchange rate risks. The Russian example presents a very relevant setting to test the evolution of informed trading activity during a period of international tension given its high level of corruption ${ }^{4}$ and model of "crony capitalism" following the collapse of the USSR. For example, Goriaev and Sonin (2005) explore Russian market reaction to the arrest and prosecution of Khodorkovsky, the leader of Russian oil company Yukos. This arrest demonstrated the fragile nature of Russian property rights and thus was an indicator of increased political risks. Goriaev and Sonin (2005) show other oil and non-oil company stock prices reacted negatively to the negative news about Yukos.

Finally, our work not only adds to the voluminous literature of market microstructure, but also provides guidance to practitioners and regulators that VPIN can potentially be used not only to predict market-specific crashes as documented by (Easley, López de Prado, and O'Hara 2011) but also to anticipate negative price reactions associated to broader events.

The remainder of the paper is organized as follows. We describe the evolution of the Crimean crisis and provide a brief background on its causes (Section 2). We then describe our data and sample selection criteria (Section 3) and present our empirical results (Section 4). We conclude by proposing how our results can be employed by regulators and practitioners (Section 5).

\section{The Crimean Crisis - A Brief Background}

Crimea was politically a territory of Russia since 1783 and remained Russian until 1954, when the Soviet leader Nikita Khrushchev decided to transfer the Crimea region to the Ukrainian Republic within the USSR. Consequently Crimea remained part of Ukraine following the collapse of Soviet Union. This decision was criticized by both Russians and Crimeans alike - according to the 2001 census, $58 \%$ of this region self-identifies as Russian and $71 \%$ of its population have Russian as their native language. From a geopolitical standpoint, Crimea has a significant military and recreational value for the Russian Federation.

In the fall of 2013, Ukranian President Viktor Yanukovych postponed the signing of the Ukraine-European Union Association Agreement in favor of a different agreement with the Russian Federation. Starting in Kiev, protests by pro-European Ukrainians spread across the Crimean region. In response, Russia began its military involvement in Crimea.

The following Table 1 outlines the sequence of important events that led to Russia's military intervention, starting on February $23^{\text {rd }}, 2014$.

\footnotetext{
${ }^{4}$ According to Transparency International Russia scored 28 out of 100 on its 2013 Corruption Perceptions Index (lower values means higher corruption perception), which corresponds to a rank of 127 out of 177 countries (rank 1 being the less corrupt).
} 
Table 1: Timeline of important events of the Crimean Crisis

Date Description

February $23^{\text {rd }}$

"Euromaidan" protests started in Simferopol, the administrative center of the Crimea region. At the same time, pro-Russian protests also started in Crimea. These protests gained attention from both the Russian and the new Ukrainian governments.

February $24^{\text {th }}$

Several media articles reported that Russian military ships with soldiers had arrived at the Crimean coast.

February $26^{\text {th }}$

Vladimir Putin put military forces in western Russia on alert. Despite the proximity of this region to the Ukrainian border, Russian Defense Minister Sergei Shoigu stated that this drill was not linked to Ukrainian events. However, he also added a separate remark that Russia is "carefully watching what is happening in Crimea".

February $28^{\text {th }}$

The airport in Simferopol was seized by unknown military troops. While these troops were wearing Russian military uniforms and speaking in Russian, Vladimir Putin denied that these troops were part of the Russian Army.

March $1^{\text {st }}$

Crimean leader Sergei Aksyonov appealed to Russian president Vladimir Putin, asking Russia "to provide assistance in securing peace." At the same time, Vladimir Putin formally asked the Federation Council to permit to "use the armed forces of the Russian Federation on the territory of Ukraine until the normalization of the socio-political situation in the that country". The Federation Council granted this permission several hours afterwards.

March $2^{\text {nd }}$

Ukrainian military bases in Crimea were seized by the military troops seen in Crimea several days before. According to some rumors Russia has sent additional military units to Crimea.

March $4^{\text {th }}$

Putin commanded Russian troops to end the military exercises. Additionally, he stated that he is not planning any military involvement in Crimea and denied that the military troops seen in Crimea were Russian.

March $12^{\text {th }}$

Crimean Parliament decided to determine Crimean status by a referendum on March $16^{\text {th }}$.

March $16^{\text {th }}$

In a referendum, $95 \%$ of Crimeans voters supported the Russian annexation of Crimea. 


\section{Data and Sample Selection}

We collect both intraday data of trades and quotes, as well as firm-specific characteristics of Russian equities from Bloomberg. We perform an initial screening on the stocks traded at MCX Exchange by taking the daily average liquidity of the past 30 days and filtering those equities whose average liquidity (measured as of June $12^{\text {th }} 2014$ ) is greater than the $1,000.00$ RUB threshold. This yields a sample of 161 firms. We also collect intraday data of 16 depositary receipts of Russian equities traded in the London Stock Exchange and Eurex.

In order to maintain time consistency, the time-stamps considered for the remainder of this paper will be the US Eastern Standard Time (EST) regardless of which market the security is traded in. For example, during the period from January $6^{\text {th }}$ (the first trading day in Russia after its national holidays), 2014 to April $4^{\text {th }}, 2014$ the Russian market opens at 9:30AM (local time) and closes 7:00PM (also local time). Because of the daylight savings on March $9^{\text {th }}$ in the US, ${ }^{5}$ our time stamps seen in EST ranges from 00:30AM to 10:00AM from January $9^{\text {th }}$ to March $7^{\text {th }}$ and shifts from 01:30AM to 11:00AM starting on March $11^{\text {th }}$.

The firm level data is comprised by (i) the firm's market capitalization, (ii) the firm's trading volume and (iii) the fraction of the firm's shares owned by the Russian government. ${ }^{6}$

\section{Empirical Results}

We start our analysis by computing and populating VPIN time series for RTS index level (with index futures contracts) and for the individual stocks obtained by the screening process described in Section 3. The algorithm used to compute VPIN follows the exact procedure described by the supplementary section of Easley, López de Prado, and O'Hara (2012), requiring as inputs just a sequence of tuples (time stamp, volume, and price) associated to trades. In accordance with their original work, we also define the standard volume-bucket size for each underlying asset (index and individual stocks) as one fifth of the average daily volume of the corresponding security. ${ }^{7}$

Mid-quotes are also computed and considered as a proxy for the underlying price. As a proxy for liquidity, we also compute time series of percent quoted spreads. The next subsections comprise the main results found for index and stock level data.

\subsection{VPIN and RTS Index Prices}

The RTS index consists of 50 of the most liquid Russian Stocks; its futures are the most traded securities on the Russian Exchange. These futures were $7^{\text {th }}$ in the trading volume among most traded futures and options worldwide. ${ }^{8}$ For our analysis, we look at the behavior of future contract on RTS index between January $14^{\text {th }}$ and March $15^{\text {th }}$.

Fig. 1 shows the dynamics of the RTS index futures price and its VPIN from the $1^{\text {st }}$ of February 2014 until the $5^{\text {th }}$ of March 2014. The average value of VPIN for this security is around $34 \%$ and it spikes up to $54 \%$ two trading days before the market crash. Fig. 2 provides a more detailed graph of futures price, VPIN, and its empirical cumulative distribution function

\footnotetext{
${ }^{5}$ Russia has been abolishing its Daylights Savings since 2011 in different locations and has it completely terminated in 2014

${ }^{6}$ Government equity ownership is an important feature of State Capitalism and it is relevant in this case not only because government owned firms are likely to be more affected by a prospective war but also because high government ownership is associated with lower turnover ratios (as governments don't trade their stocks except in special cases such as privatizations).

${ }^{7}$ This choice of the volume-bucket size ensures that, by construction, a day of typical trading volume would be spanned by 50 volume-buckets.

${ }^{8}$ http://www.futuresindustry.org/downloads/Volume-Mar_FI(R).pdf
} 
(CDF) around the event. The CDF was estimated based on the empirical values of VPIN from Februrary $1^{\text {st }}$ to $15^{\text {th }}$. The intuition behind computing this measure is to reflect, for a given time, the probability that the current value of VPIN is above usual levels. Easley, López de Prado, and O'Hara (2012) argue that CDF values higher than 0.9 are a strong signal for suspicious market conditions. Fig. 2 narrows the plot of Fig. 1 and displays that CDF levels were higher than 0.9 for most of the previous two days.

\subsection{VPIN and Individual Equity Prices}

As we document a considerable spike in the levels of VPIN (and its cumulative distribution) two days before the Russian Army's invasion of Crimea, a natural follow up question is whether such patterns are also observable at the individual equity level. The rationale of short-sellers trading on the index level is that (i) a war is a major event affecting the whole Russian economy and (ii) the index liquidity allows traders to minimize the price impact from executing market orders.

There are reasons to believe VPIN spikes are also observed at individual equity levels as well. First, indexes are, by construction, baskets of individual stocks. Second, although a war is a systematic event, there are certainly differential (negative) impacts to different firms. Oil and gas companies, for example, are more likely to suffer from the effect of Western sanctions. Hence, investors could be able to handpick stocks which are more likely to experience higher drops from the event and actively trade them in advance.

The following Figs. 3, 4, 5, and 6 illustrate the patterns of VPIN (and its CDF) for Tatneft (Oil and Gas, ticker: TATN), RusHydro (Utilities / Hydroelectricity, ticker: HYDR), Rosseti (Power distribution company, Ticker: RSTI), and Novolipetsk Steel (Metals, ticker: NLMK), respectively.

While it is possible to observe spike patterns for most equities, we fail to find evidence of any relationship between the intensity of market price drop after the invasion and the levels of VPIN prior to the event. We also find no relationship between informed trading and industry or degrees of government equity ownership.

Possible explanations (although not comprehensive) include:

- Although informed traders knew exactly the day the invasion would take place, it required a higher degree of sophistication to choose the specific stocks which would experience the largest price drops.

- The liquidity of the Russian stock market is indeed very skewed and concentrated in fewer equities. This would suggest that short-selling the RTS index would be more reasonable for liquidity purposes.

- For less liquid stocks, VPIN is less representative of information-driven trades, preventing statistical associations between informed trading and market price drops from being drawn.

- Lack of statistical power when conducting a cross-sectional analysis of VPIN peaks and market drops.

\subsection{Predictive Power of VPIN Time series}

As previously mentioned, the purely cross-sectional nature of the test may account for the failure to find evidence of a relationship between stock returns on March $3^{\text {rd }}, 2014$ and the maximum level of VPIN within the fixed time frame of 2 trading days prior to the invasion is the purely cross-sectional nature of the test.

Although March $3^{\text {rd }}$ corresponds to a main turning point during the Russian-Ukrainian crisis, tensions actually evolved over a longer period of few months. Thus, we widen the scope 
of our study and conduct a panel analysis of return predictability of VPIN of different stocks as the political tensions between both nations evolved. We focus our analysis to the period ranging from February $1^{\text {st }}$ until April $1^{\text {st }}, 2014$. We filter our sample of securities by eliminating those stocks with at least one trading day not covered by a single volume-bucket - therefore ensuring the panel data is fully saturated and eliminating less liquid stocks for which VPIN is not an effective proxy measure for information-based trades. This filter yields a final sample of 143 stocks. The following generalized model is estimated for this purpose:

$$
\text { ret }_{i, t}=\alpha+\beta \cdot c d f_{i, t-1}+\text { controls }+\epsilon_{i, t}
$$

where ret $_{i, t}$ is a return of stock $i$ during day $t, c d f_{i, t}$ is the maximum CDF value of stock $i$ 's VPIN during the day $t$. Table 2 shows the results of such regressions. Model (1) illustrates that lagged values of VPIN's CDF daily maximum are significantly negatively correlated with stock returns. Model (2) controls for average values of stocks' spread over the two week period before the start of our time interval which is used as a proxy of stock market liquidity.

Short selling is permitted on the Russian stock market only for a subset of stocks defined by the local securities authority. At the beginning of each quarter the Federal Financial Markets Service (FFMS) publishes a list of stocks and bonds for which short selling is allowed. The FFMS typically selects the most liquid traded assets. In our sample of 143 firms, 31 stocks were cleared for short selling in the quarter from January $14^{\text {th }}$ to March $27^{\text {th }}$. Model (3) investigates whether there is an interaction effect of the shortselling constraints and the predictive power of the CDF of VPIN. We expected CDF to have higher predictive power for stocks for which short selling is allowed because informed traders would be able to gain on both positive and negative information associated with these stocks, whereas for the stocks with short selling constraints informed traders could simply "avoid losses" in previously long portfolios. We fail to find evidence of a stronger effect for stocks where short selling is allowed. Model (4) includes controls for firm fixed effects. Generally speaking, we show evidence that higher values of the CDF of VPIN are associated with lower returns in the subsequent day.

Table 3 shows how the forecasting power of VPIN and its CDF interacts with the level of government equity ownership. We create $N_{o G o v}$ as dummy variable for the companies whose stocks are not held by the government and HighGov $i$ as a dummy for the companies in which government owns more than $90 \%$ of stocks. Models (1) to (3) in Table 3 indicate that companies with moderate amount of government ownership are more sensitive to the informed trader's activity, and so their VPIN's CDF has a stronger predictive power. This is consistent with the intuition that independent companies without any governmet ownership have their managment more aligned with the best interests of their common shareholders. On the other hand, companies with high goverment ownership are expected to be financially backed up by the government and are therefore less prone to be affected by any adverse shock in the first place. During bad times these companies have access to additional benefits: tax benefit, subsidized loans, etc., extracted from their political connections. For instance, Igor Sechin, the chairman of Rosneft, the largest publicly traded oil company in the world, directly asked Russian government to cover their $\$ 42$ billion debt. ${ }^{9}$

\subsection{VPIN and Foreign Depositary Receipts}

Although our study focuses on the cross-sectional differences within the set of Russian equities whose daily trading volume ranges from 22 billion RUB to relatively illiquid stocks, some of the high trading volume equities in Russia also have their corresponding Depositary Receipts (mainly in London or EU). As Depositary Receipts are by construction cash flow claims backed

\footnotetext{
${ }^{9}$ http://www.dw.de/russias-rosneft-pleads-for-debt-relief-amid-western-sanctions/a-17854908
} 
Table 2: Predictive Power of VPIN in Panel Level. This model shows that maximum value of the CDF of stocks' VPIN during the previous day $\left(c d f_{i, t-1}\right)$ has a significant forecasting power for stocks' returns ret $_{i, t}$. These results are estimated for the 143 most liquid firms traded on MICEX, the Russian Stock Exchange, from February 1 ${ }^{\text {st }}, 2014$ until April 1 ${ }^{\text {st }}, 2014$. Model (2) controls for the average value of relative spread during previous two weeks. In Model (3) we isolate the predictive power for firms that cannot be short sold. In Model (4) we control for firm fixed effects.

\begin{tabular}{|c|c|c|c|c|}
\hline & \multicolumn{4}{|c|}{ Dependent variable: } \\
\hline & \multicolumn{4}{|c|}{ ret $_{i, t}-$ Return in $\%$} \\
\hline & (1) & $(2)$ & $(3)$ & $(4)$ \\
\hline$c d f_{i, t-1}$ & $\begin{array}{c}-0.369^{*} \\
(0.219)\end{array}$ & $\begin{array}{c}-0.389^{*} \\
(0.220)\end{array}$ & $\begin{array}{c}-0.559^{*} \\
(0.291)\end{array}$ & $\begin{array}{c}-0.644^{* *} \\
(0.267)\end{array}$ \\
\hline$c d f_{i, t-1} \cdot$ no_short $_{i}$ & & & $\begin{array}{c}0.212 \\
(0.237)\end{array}$ & \\
\hline spread $_{i}$ & & $\begin{array}{l}-1.214 \\
(1.322)\end{array}$ & $\begin{array}{l}-1.543 \\
(1.372)\end{array}$ & \\
\hline Firm Fixed Effects & - & - & - & + \\
\hline Constant & $\begin{array}{c}0.056 \\
(0.146)\end{array}$ & $\begin{array}{c}0.105 \\
(0.156)\end{array}$ & $\begin{array}{c}0.117 \\
(0.156)\end{array}$ & $\begin{array}{c}0.158 \\
(0.725)\end{array}$ \\
\hline Observations & 5,033 & 5,033 & 5,033 & 5,033 \\
\hline $\mathrm{R}^{2}$ & 0.001 & 0.001 & 0.001 & 0.018 \\
\hline Adjusted $\mathrm{R}^{2}$ & 0.0004 & 0.0003 & 0.0003 & -0.011 \\
\hline Note: & & ${ }^{*} \mathrm{p}<0$ & $* * \mathrm{p}<0.0$ & ${ }^{* * *} \mathrm{p}<0.01$ \\
\hline
\end{tabular}


Table 3: VPIN's Predictive Power and Government Ownership. This model shows that maximum value of the CDF of stocks' VPIN during the previous day $\left(c d f_{i, t-1}\right)$ has a significant forecasting power for stocks' returns ret $_{i, t}$. These results are estimated for the 143 most liquid firms traded on MICEX, the Russian Stock Exchange, from February 1 ${ }^{\text {st }}, 2014$ until April 1 ${ }^{\text {st }}, 2014$. NoGov $i$ is a dummy for companies in which the Russian government does not own any shares. HighGovi is a dummy for companies where government owns more than $90 \%$ of shares.

\begin{tabular}{|c|c|c|c|}
\hline & \multirow{2}{*}{\multicolumn{3}{|c|}{$\frac{\text { Dependent variable: }}{\text { ret }_{i, t}-\text { Return in } \%}$}} \\
\hline & & & \\
\hline & (1) & $(2)$ & $(3)$ \\
\hline$c d f_{i, t-1}$ & $\begin{array}{c}-0.502^{* *} \\
(0.240)\end{array}$ & $\begin{array}{c}-0.398^{*} \\
(0.223)\end{array}$ & $\begin{array}{c}-0.551^{* *} \\
(0.251)\end{array}$ \\
\hline$c d f_{i, t-1} \cdot N_{o G o v}$ & $\begin{array}{c}0.228 \\
(0.193)\end{array}$ & & $\begin{array}{c}0.274 \\
(0.205)\end{array}$ \\
\hline$c d f_{i, t-1} \cdot$ HighGov $_{i}$ & & $\begin{array}{c}0.077 \\
(0.301)\end{array}$ & $\begin{array}{c}0.219 \\
(0.319)\end{array}$ \\
\hline spread $_{i}$ & $\begin{array}{l}-1.647 \\
(1.372)\end{array}$ & $\begin{array}{l}-1.192 \\
(1.325)\end{array}$ & $\begin{array}{l}-1.675 \\
(1.373)\end{array}$ \\
\hline Constant & $\begin{array}{c}0.119 \\
(0.156)\end{array}$ & $\begin{array}{c}0.105 \\
(0.156)\end{array}$ & $\begin{array}{c}0.122 \\
(0.156)\end{array}$ \\
\hline Observations & 5,033 & 5,033 & 5,033 \\
\hline $\mathrm{R}^{2}$ & 0.001 & 0.001 & 0.001 \\
\hline Adjusted $\mathrm{R}^{2}$ & 0.0004 & 0.0001 & 0.0003 \\
\hline Note: & ${ }^{*} \mathrm{p}<0$ & ${ }^{* *} \mathrm{p}<0.05$ & ${ }^{* * *} \mathrm{p}<0.01$ \\
\hline
\end{tabular}


Table 4: List of Russian-Depositary Receipt pairs

\begin{tabular}{lccc}
\hline Firm Name & Ticker (local) & DR Location & DR Ticker \\
\hline & & & \\
Sberbank Rossii OAO & SBER & London & SBER \\
Sberbank Rossii OAO & SBER & Europe & SBER \\
Gazprom OAO & GAZP & London & OGZD \\
Gazprom OAO & GAZP & Europe & OGZD \\
Rosneft' NK OAO & ROSN & London & ROSN \\
Rosneft' NK OAO & ROSN & Europe & ROSN \\
Uralkaliy OAO & URKA & London & URKA \\
Uralkaliy OAO & URKA & Europe & URKA \\
Novatek OAO & NVTK & London & NVKT \\
Novatek OAO & NVTK & Europe & NVKT \\
Magnit OAO & MGNT & London & MGNT \\
Magnit OAO & MGNT & Europe & MGNT \\
RusHydro OAO & HYDR & London & HYDR \\
Severstal' OAO & CHMF & London & SVST \\
AFK Sistema OAO & AFKS & London & SSA \\
Novolipetskiy metallurg. komb. OAO & NLMK & London & NLMK \\
PhosAgro OAO & PHOR & London & PHOR \\
Gruppa LSR OAO & LSRG & London & LSRG \\
\hline
\end{tabular}

by the same firm, it raises the issue of how informed trading activities may differ between the local securities traded in Russia and their DRs traded in other market.

The hypothesis that domestic securities and their corresponding Foreign Depositary Receipts have different investor clientele is widely supported by the literature (Gagnon and Karolyi 2009, 2010, Kato, Linn, and Schallheim 1990). Gagnon and Karolyi (2009) investigates the joint dynamics of foreign stocks and ADRs, showing that returns in one market during days of high trading volume are more likely to generate a spillover effect to the other market for those stocks with higher risk of information-based trading.

We perform our analysis by creating pairs of equity securities for Russian firms in our sample traded at the local exchange and their corresponding Depositary Receipts. For each pair we analyze how patterns of VPIN and its CDF evolve as we get close to the event date. Table 4 depicts the list of RD-Local pairs.

Figs. 7, 8, and 9 depict how VPIN series behave for Magnit, Sberbank Rossi, and Rosneft NK, respectively.

Peaks of VPIN for the Depositary Receipt may be higher or lower than the peaks for the local securities. However, out of 18 Local-DR pairs we find that 14 have the corresponding VPIN peak earlier for the local securities than in the foreign market. The "time stamp" of the maximum VPIN (considering a period of 5 trading days before the event) for the foreign market occurs on average 127 minutes after it spikes for the Russian market (the distribution median of the time difference is 169 minutes).

One possible explanation for this pattern is that the investor clientele of foreign Depositary Receipts of Russian firms could be mainly ETFs or other types of institutional investors that necessarily need to have a given exposure to the Russian main equities because of their portfolios' policies. On the other hand, informed investors possibly linked to Russian top government officials hold portfolios in local markets due to (lack of) transparency and regulation. 


\section{Conclusion}

In this paper we exploit the tensions between the Russian Federation and Ukraine which originated from a political issue unrelated to the Russian stock market and investigate how the evolution of informed trading activities anticipated a main event of the crisis - the invasion of the Crimean region by the Russian Army. In addition to showing that the intensity of informationbased trading increased to unusually high values in the days leading up to the event (at both the index and individual equity levels), we also show that across the whole period of escalating tensions between the two countries, the CDF of VPIN has predictive power for stock returns. 


\section{References}

Amihud Y, Wohl A (2004) Political news and stock prices: The case of saddam hussein contracts. Journal of banking \& Finance 28(5):1185-1200

Ané T, Geman H (2000) Order flow, transaction clock, and normality of asset returns. The Journal of Finance 55(5):2259-2284

Bailey W, Chung YP (1995) Exchange rate fluctuations, political risk, and stock returns: some evidence from an emerging market. Journal of Financial and Quantitative Analysis 30(04):541-561

Duarte J, Young L (2009) Why is pin priced? Journal of Financial Economics 91(2):119-138

Easley D, O'Hara M (2004) Information and the cost of capital. The journal of finance $59(4): 1553-1583$

Easley D, Kiefer NM, O'Hara M, Paperman JB (1996) Liquidity, information, and infrequently traded stocks. The Journal of Finance 51(4):1405-1436

Easley D, Hvidkjaer S, O'Hara M (2002) Is information risk a determinant of asset returns? The journal of finance 57(5):2185-2221

Easley D, López de Prado MM, O'Hara M (2011) The microstructure of the flash crash: Flow toxicity, liquidity crashes and the probability of informed trading. Journal of Portfolio Management 37(2):118-128

Easley D, López de Prado MM, O'Hara M (2012) Flow toxicity and liquidity in a high-frequency world. Review of Financial Studies p hhs053

Frey BS, Kucher M (2000) History as reflected in capital markets: the case of world war ii. The Journal of Economic History 60(02):468-496

Gagnon L, Karolyi GA (2009) Information, trading volume, and international stock return comovements: Evidence from cross-listed stocks. Journal of Financial and Quantitative Analysis $44(04): 953-986$

Gagnon L, Karolyi GA (2010) Multi-market trading and arbitrage. Journal of Financial Economics 97(1):53-80

Goriaev A, Sonin K (2005) Is political risk company-specific? the market side of the yukos affair

Karolyi GA (2015) Cracking the emerging markets enigma. Oxford University Press, USA

Kato K, Linn S, Schallheim J (1990) Are there arbitrage opportunities in the market for american depository receipts? Journal of International Financial Markets, Institutions \& Money 1(1):73-89

Lee C, Ready MJ (1991) Inferring trade direction from intraday data. The Journal of Finance $46(2): 733-746$

Leigh A, Wolfers J, Zitzewitz E (2003) What do financial markets think of war in iraq? Tech. rep., National Bureau of Economic Research 
The VPIN Toxicity Metric and RTS futures prices

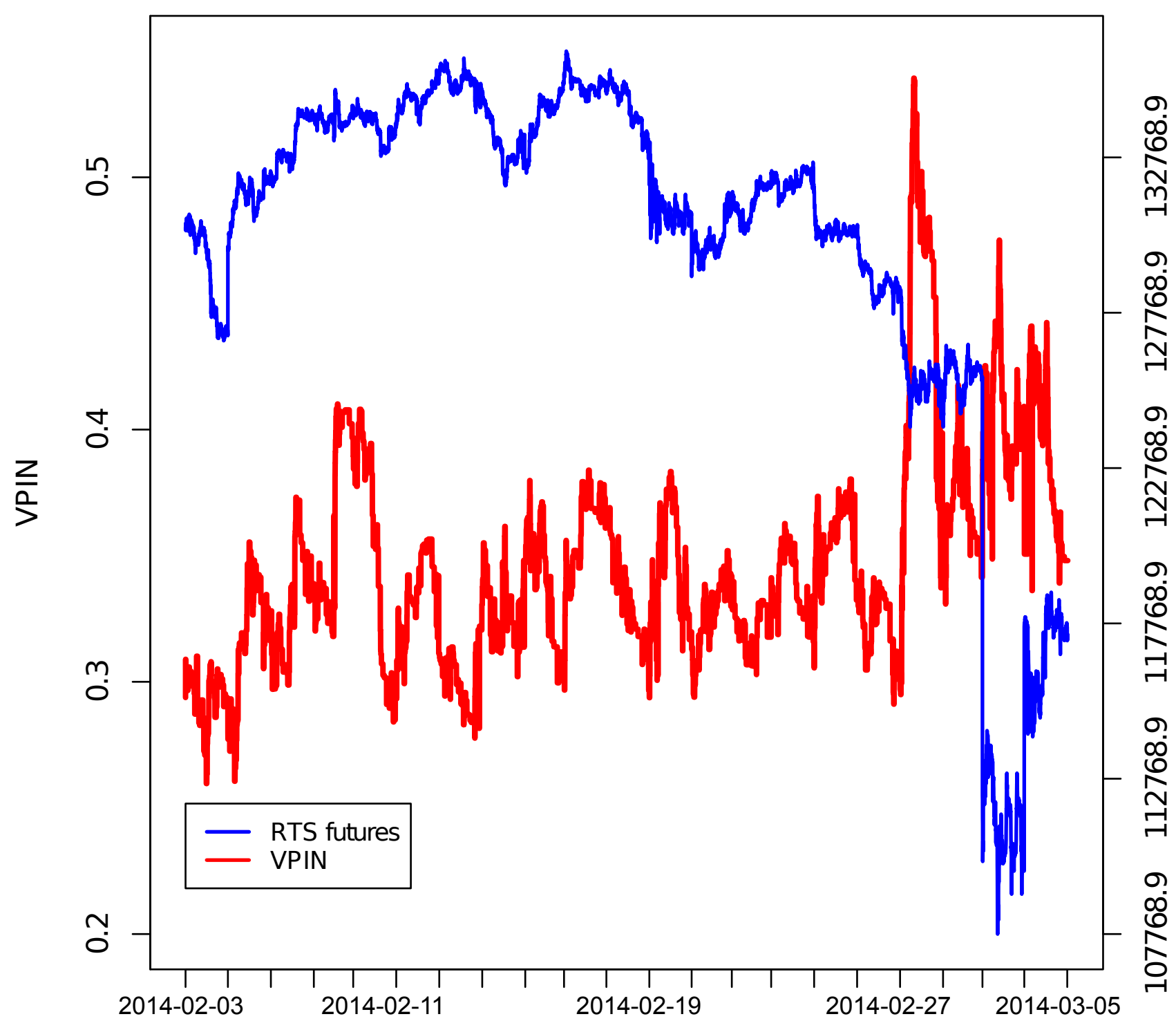

Days

Figure 1: Informed Trading Measures for RTS futures between 02-01-2014 and 03-05-2014. The red line corresponds to VPIN values and blue line corresponds to the RTS futures prices. 
The VPIN Toxicity Metric, its CDF and RTS futures prices

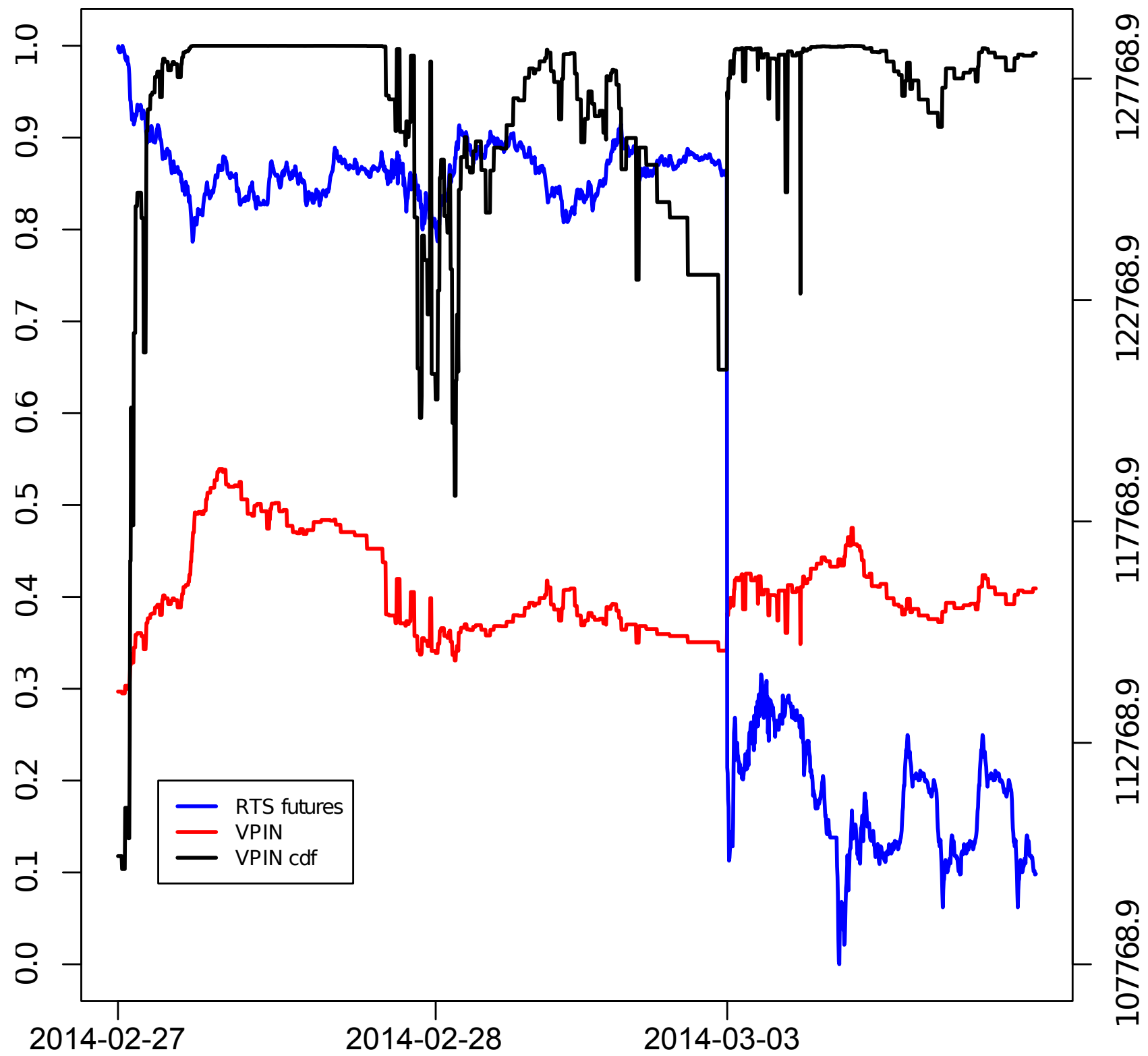

Figure 2: Informed Trading Measures for RTS futures between 02-01-2014 and 03-05-2014. The red line corresponds to VPIN values and blue line corresponds to the RTS futures prices. Black line shows the level of VPIN's CDF calculated based on the time interval from 02-01-2014 to 02-15-2014. 

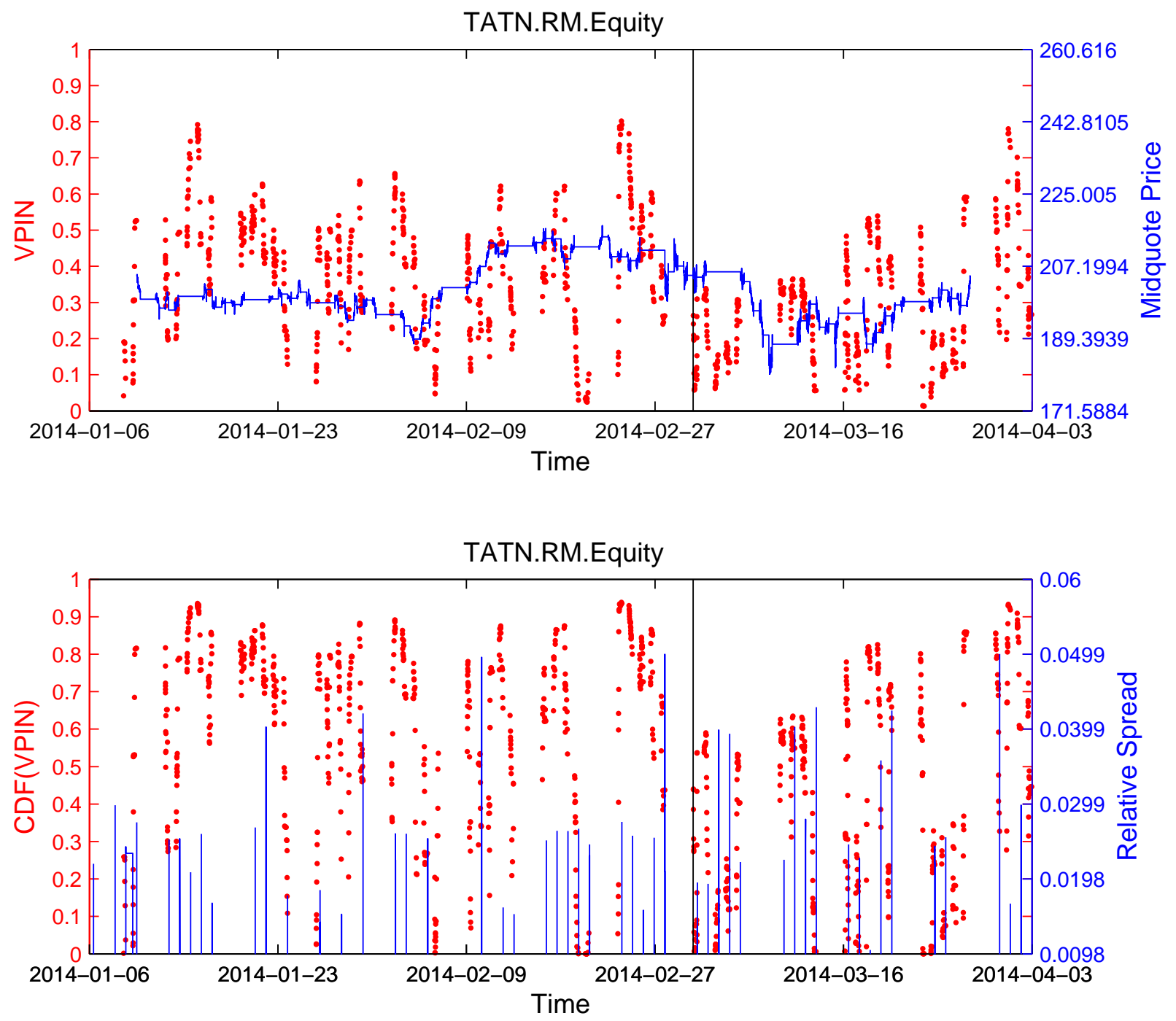

Figure 3: Informed Trading Measures for TATN between 01-06-2014 and 03-04-2014. The upper plot shows corresponding values of VPIN (red) and midquote prices (blue). The lower plot illustrates the evolution of relative (quoted) spreads (red) and the CDF of VPIN (blue). 

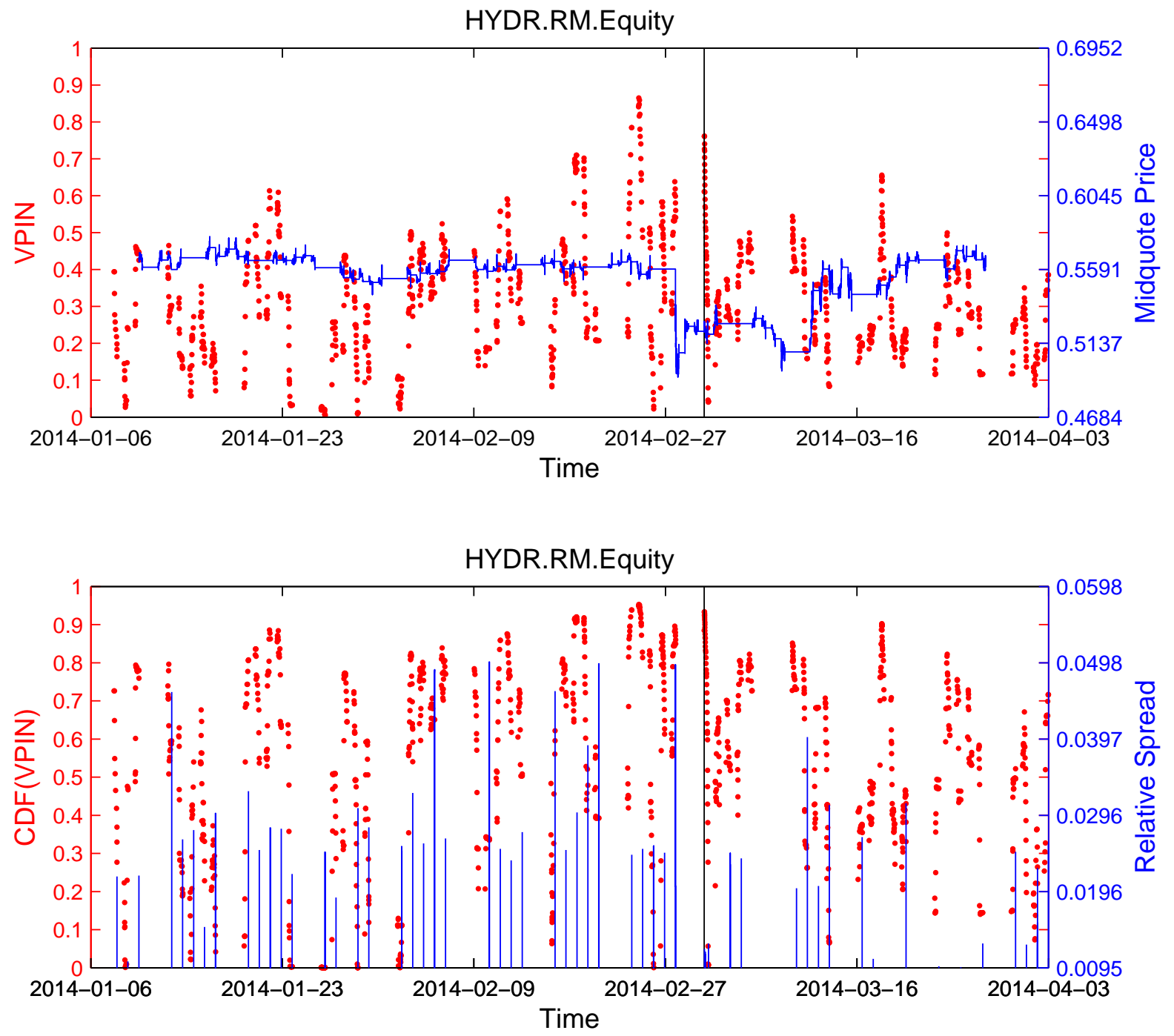

Figure 4: Informed Trading Measures for HYDR between 01-06-2014 and 03-04-2014. The upper plot shows corresponding values of VPIN (red) and midquote prices (blue). The lower plot illustrates the evolution of relative (quoted) spreads (red) and the CDF of VPIN (blue). 

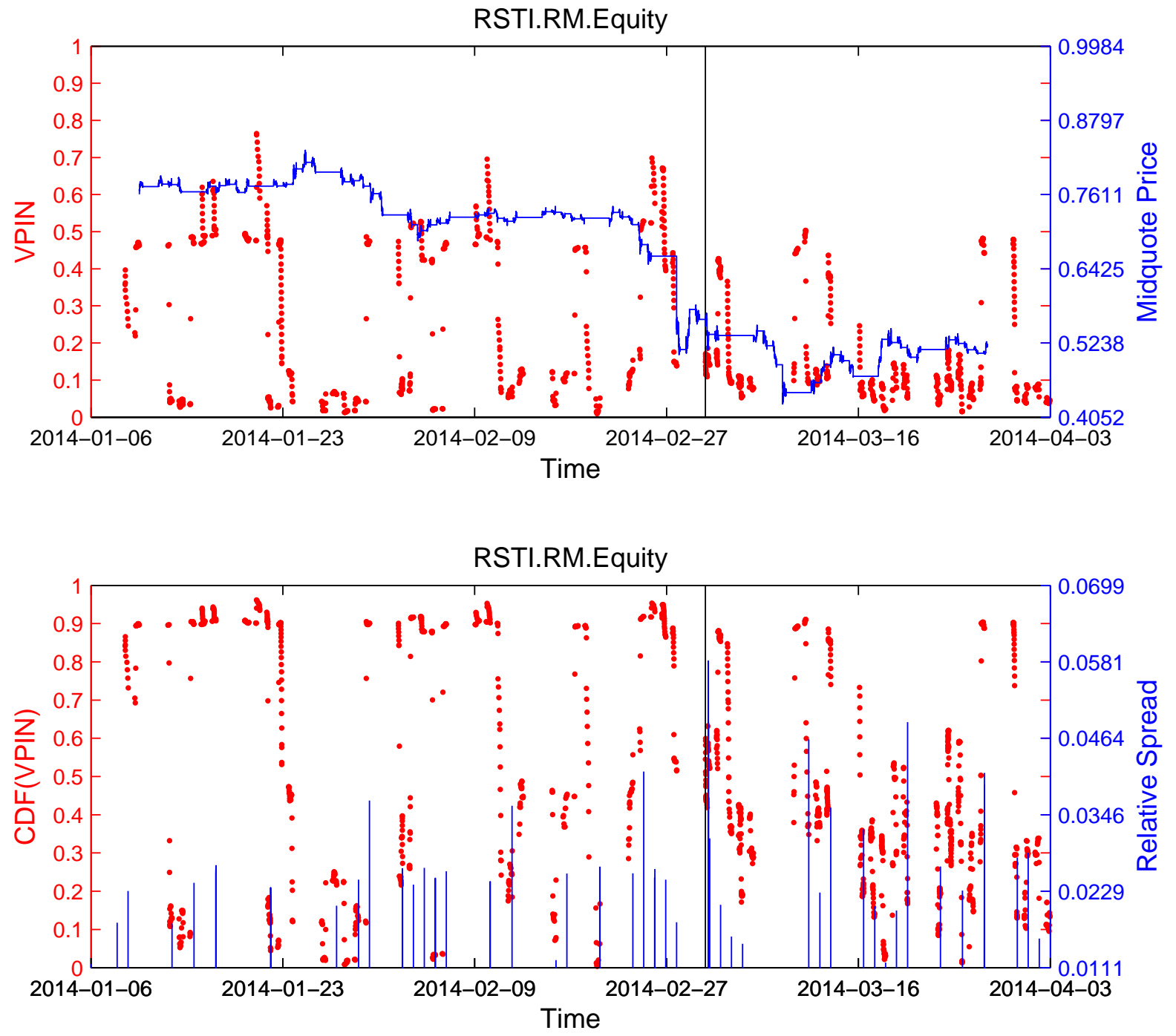

Figure 5: Informed Trading Measures for RSTI between 01-06-2014 and 03-04-2014. The upper plot shows corresponding values of VPIN (red) and midquote prices (blue). The lower plot illustrates the evolution of relative (quoted) spreads (red) and the CDF of VPIN (blue). 

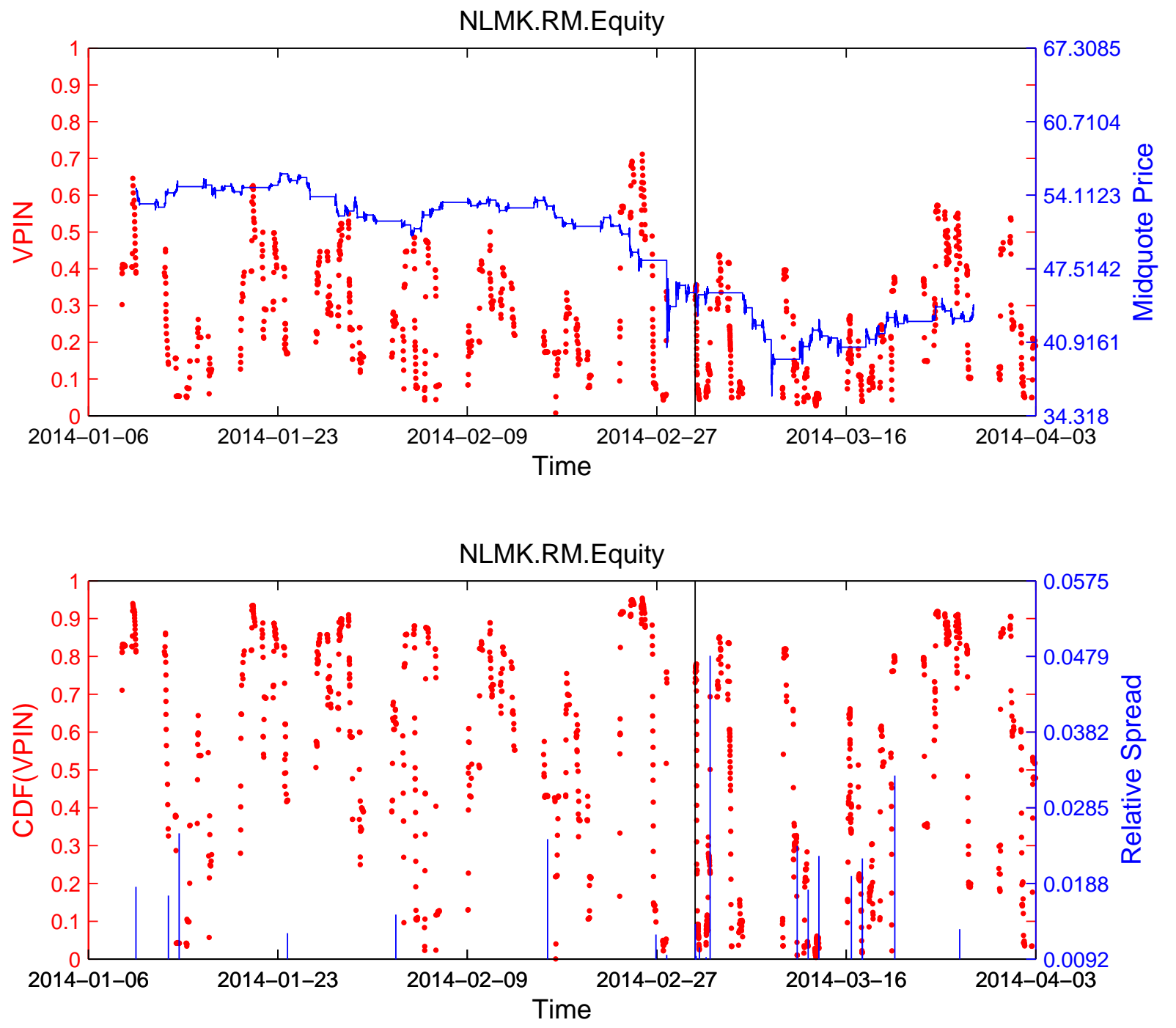

Figure 6: Informed Trading Measures for NLMK between 01-06-2014 and 03-04-2014. The upper plot shows corresponding values of VPIN (red) and midquote prices (blue). The lower plot illustrates the evolution of relative (quoted) spreads (red) and the CDF of VPIN (blue). 

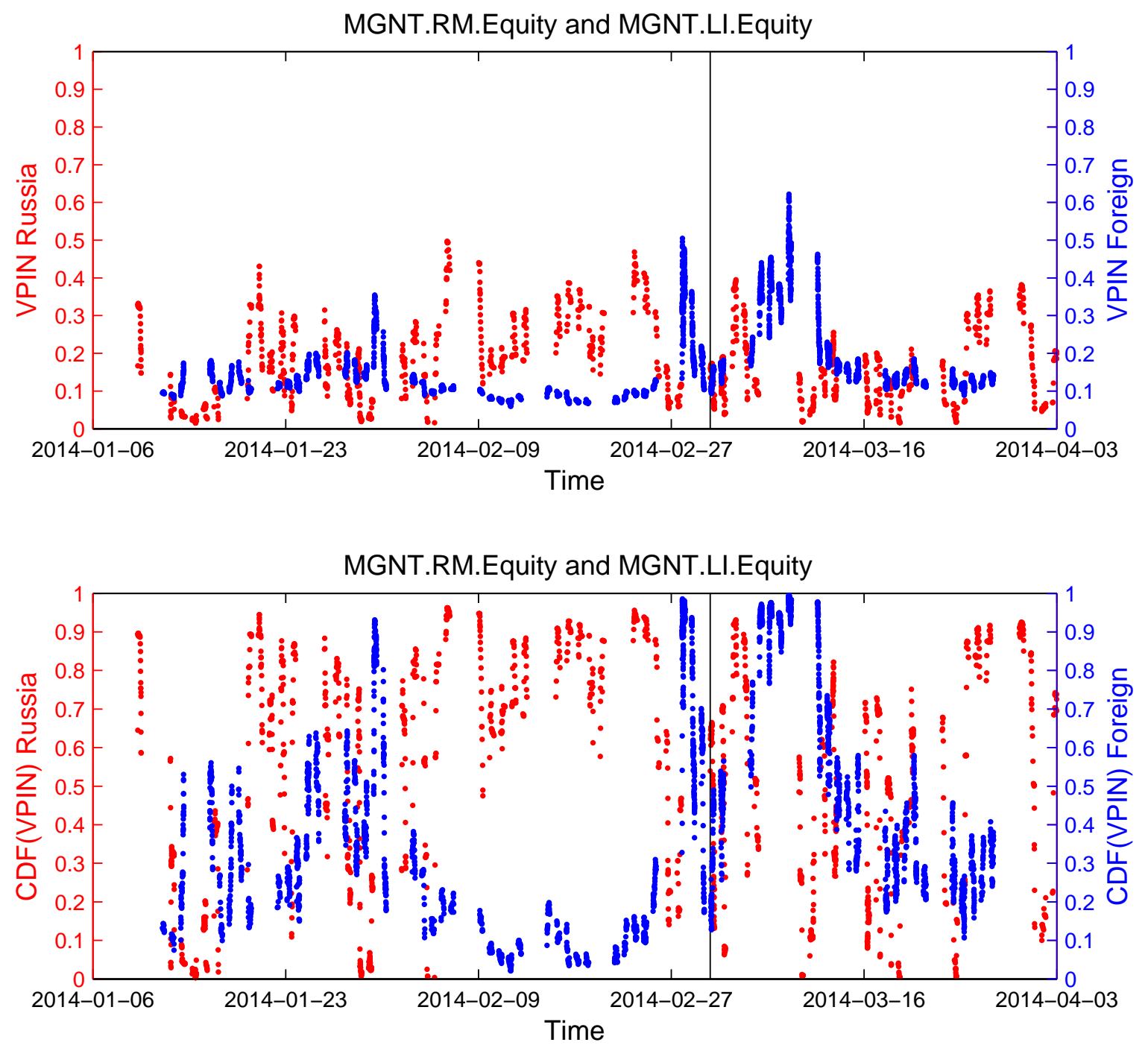

Figure 7: Plots of VPIN (top) and CDF(VPIN) (bottom) for MGNT considering the local security (red) and the corresponding depositary receipt in London (blue). 

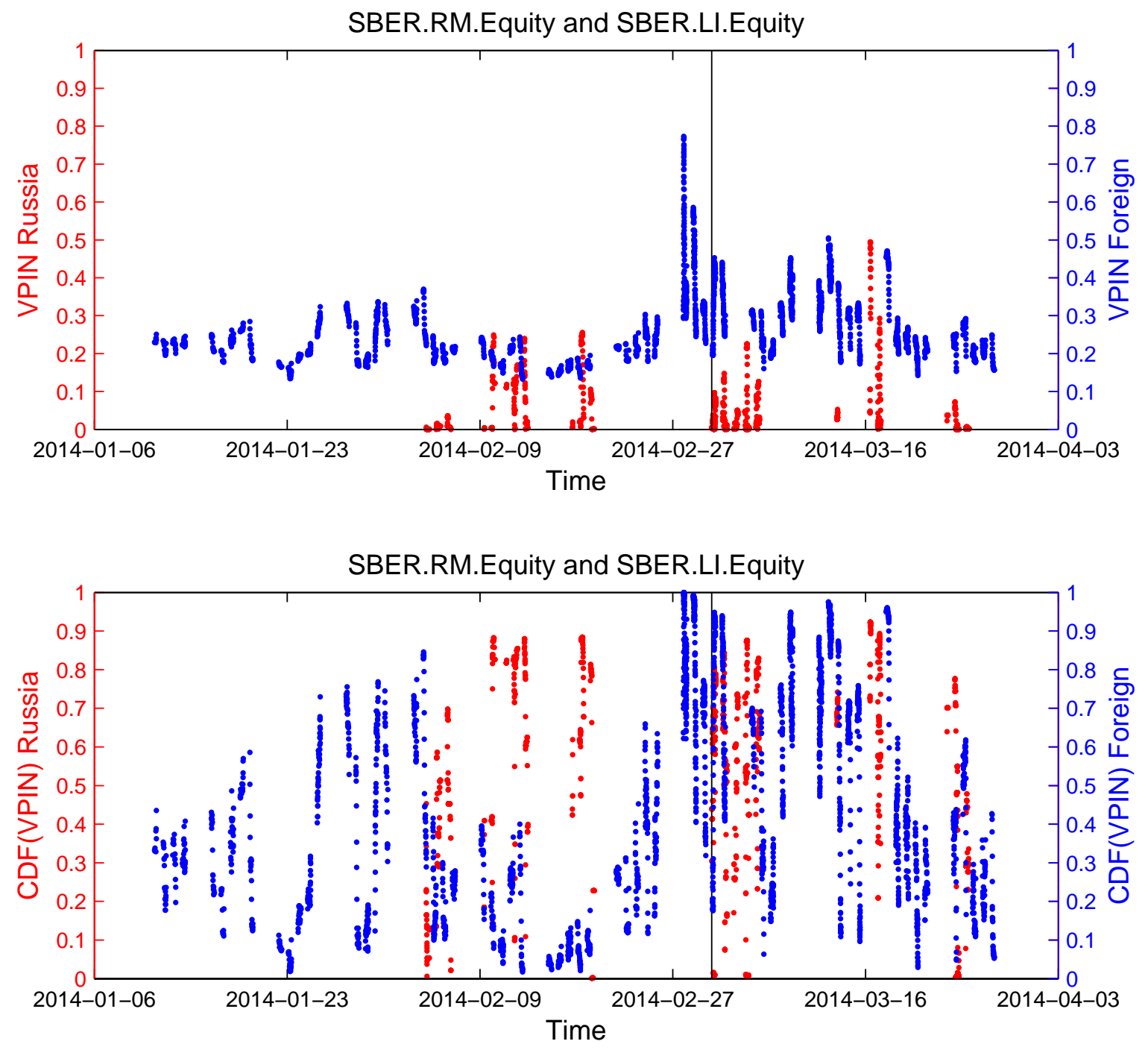

Figure 8: Plots of VPIN (top) and CDF(VPIN) (bottom) for SBER considering the local security (red) and the corresponding depositary receipt in London (blue). 

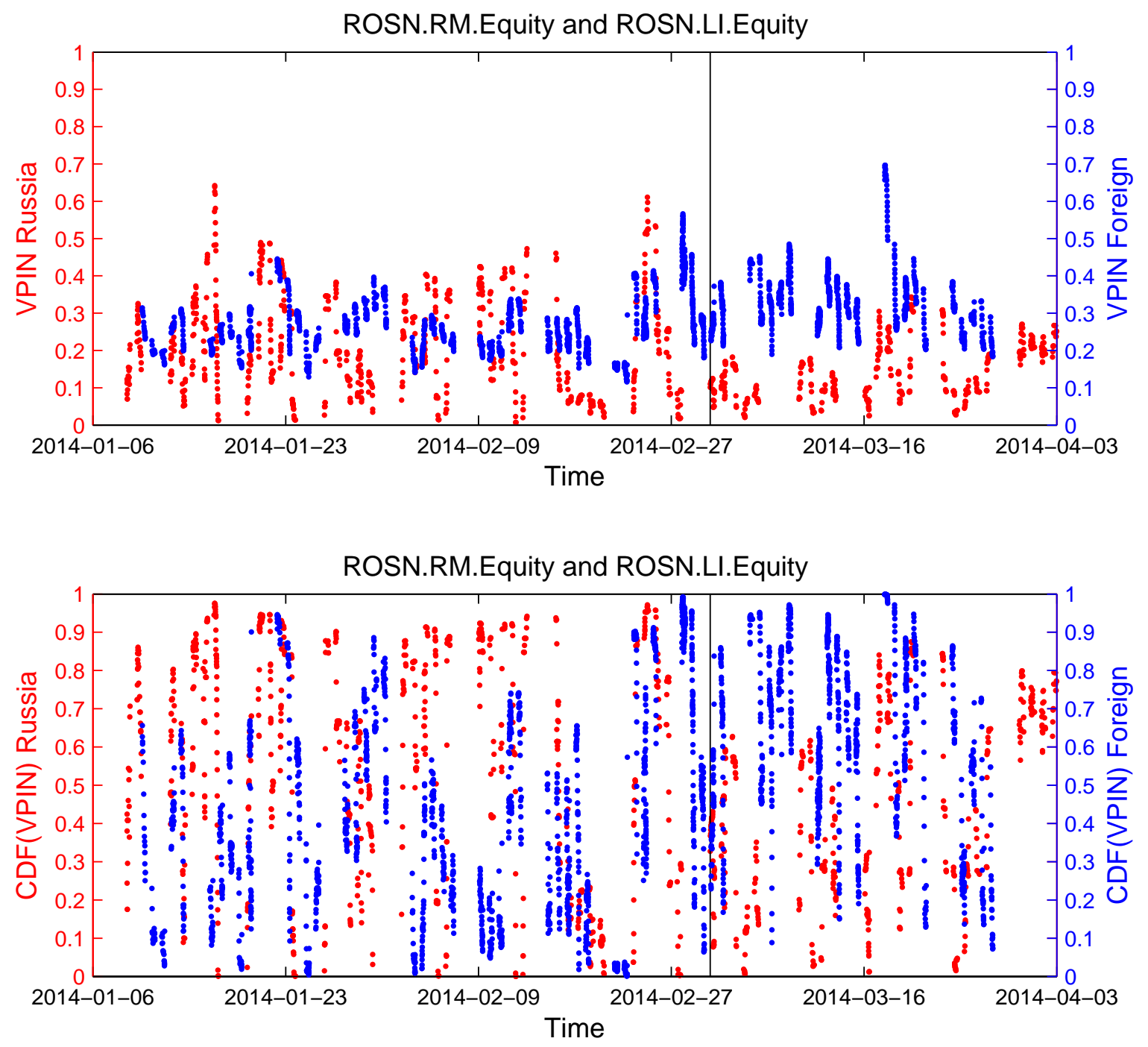

Figure 9: Plots of VPIN (top) and CDF(VPIN) (bottom) for ROSN considering the local security (red) and the corresponding depositary receipt in London (blue). 